\title{
Clinical impact of the Warburg effect in gastrointestinal cancer (Review)
}

\author{
HIROSHI SAWAYAMA ${ }^{1,2}$, TAKATSUGU ISHIMOTO ${ }^{1}$, HIDETAKA SUGIHARA ${ }^{1}$, NOBUTOMO MIYANARI ${ }^{2}$, \\ YUJI MIYAMOTO $^{1}$, YOSHIFUMI BABA ${ }^{1}$, NAOYA YOSHIDA ${ }^{1}$ and HIDEO BABA ${ }^{1}$ \\ ${ }^{1}$ Department of Gastroenterological Surgery, Graduate School of Medical Sciences, \\ Kumamoto University, Kumamoto $860-8556$; ${ }^{2}$ Department of Surgery, \\ National Hospital Organization Kumamoto Medical Center, Kumamoto 860-0008, Japan
}

Received May 24, 2014; Accepted July 9, 2014

DOI: $10.3892 /$ ijo.2014.2563

\begin{abstract}
Cancer cells exhibit altered glucose metabolism, termed the Warburg effect, which is described by the increased uptake of glucose and the conversion of glucose to lactate in cancer cells under adequate oxygen tension. Recent genetic and metabolic analyses have provided insights into the molecular mechanisms of genes that are involved in the Warburg effect and tumorigenesis. The aim of this review was to discuss significant molecular insights into clinical impacts of the Warburg effect such as oncogenic alterations and overexpression of transcriptional factors (c-Myc and hypoxia-inducible factor), metabolite transporters (glucose transporters) and glycolytic enzymes (hexokinases 2, pyruvate kinase M2, pyruvate dehydrogenase kinase, isozyme 1, lactate dehydrogenase A). Overexpression of transcriptional factors, metabolite transporters and glycolytic enzymes was associated with poor prognosis and may be associated with chemoradiotherapy resistance in multiple gastrointestinal cancer cell types. Novel small molecules targeting these enzymes or transporters exert anti-proliferative effects. Glycolytic enzymes and metabolite transporters may be significant biomarkers for predicting cancer prognosis and may be therapeutic targets in gastrointestinal cancer.
\end{abstract}

\section{Contents}

1. Introduction

2. HIF-1A and c-Myc transcription factors and the Warburg effect

3. Glucose transporters (Gluts)

4. Glycolytic enzymes (HK2, PKM2, PDK1 and LDHA)

5. Conclusions and future perspectives

Correspondence to: Professor Hideo Baba, Department of Gastroenterological Surgery, Graduate School of Medical Sciences, Kumamoto University, 1-1-1 Honjo, Kumamoto 860-8556, Japan E-mail: hdobaba@kumamoto-u.ac.jp

Key words: Warburg effect, small molecule, inhibitor, gastrointestinal cancer, prognosis

\section{Introduction}

Cancers exhibit altered glucose metabolism, defined as the Warburg effect (1), which is characterized by an increased uptake of glucose (2) and the conversion of glucose to lactate in cancer cells, rather than catabolizing glucose via the TCA cycle under adequate oxygen tension (3). While the electron transfer system generates 36 ATP molecules per glucose molecule across the mitochondrial inner membrane, glycolysis metabolizes glucose to pyruvate in the cytoplasm to produce a net 2 ATP molecules from each glucose. The Warburg effect represents high levels of glycolysis and thus enables the clinical application of metabolic imaging, such as ${ }^{18} \mathrm{~F}$-fluorodeoxyglucose positron emission tomography (FDG-PET), which is a non-invasive imaging technique that allows quantification of tumor activity on the basis of altered tissue glucose metabolism (4). Small molecule inhibitors targeting the enzymes that function in the Warburg effect have been identified and pursued in preclinical studies.

The direct mechanistic link between an activated oncogene and altered glucose metabolism is regulated by phosphoinositide 3-kinase (PI3K) (5), Akt (6), p53 $(7,8)$, AMP-activated protein kinase (AMPK) $(9,10)$, c-Myc and hypoxia-inducible factor (HIF). c-Myc and HIF1A transcription factors target many of the same glycolytic enzyme genes, including hexokinase 2 ( $\mathrm{HK} 2)$, pyruvate kinase type M2 (PKM2), lactate dehydrogenase A (LDHA), and pyruvate dehydrogenase kinase, isozyme 1 (PDK1). Recent investigations using genetic and metabolic analyses have provided insights into the molecular mechanisms of these genes that contribute to the Warburg effect and tumorigenesis (Fig. 1).

In this review, significant molecular insights into clinical impacts of the Warburg effect, such as oncogenic alterations and overexpression of glycolytic enzymes and metabolite transporters, will be discussed.

\section{HIF-1A and c-Myc transcription factors and the Warburg effect}

HIF-1A and c-Myc cooperatively induce a transcriptional program for glycolysis. HIF plays a crucial role in cellular 


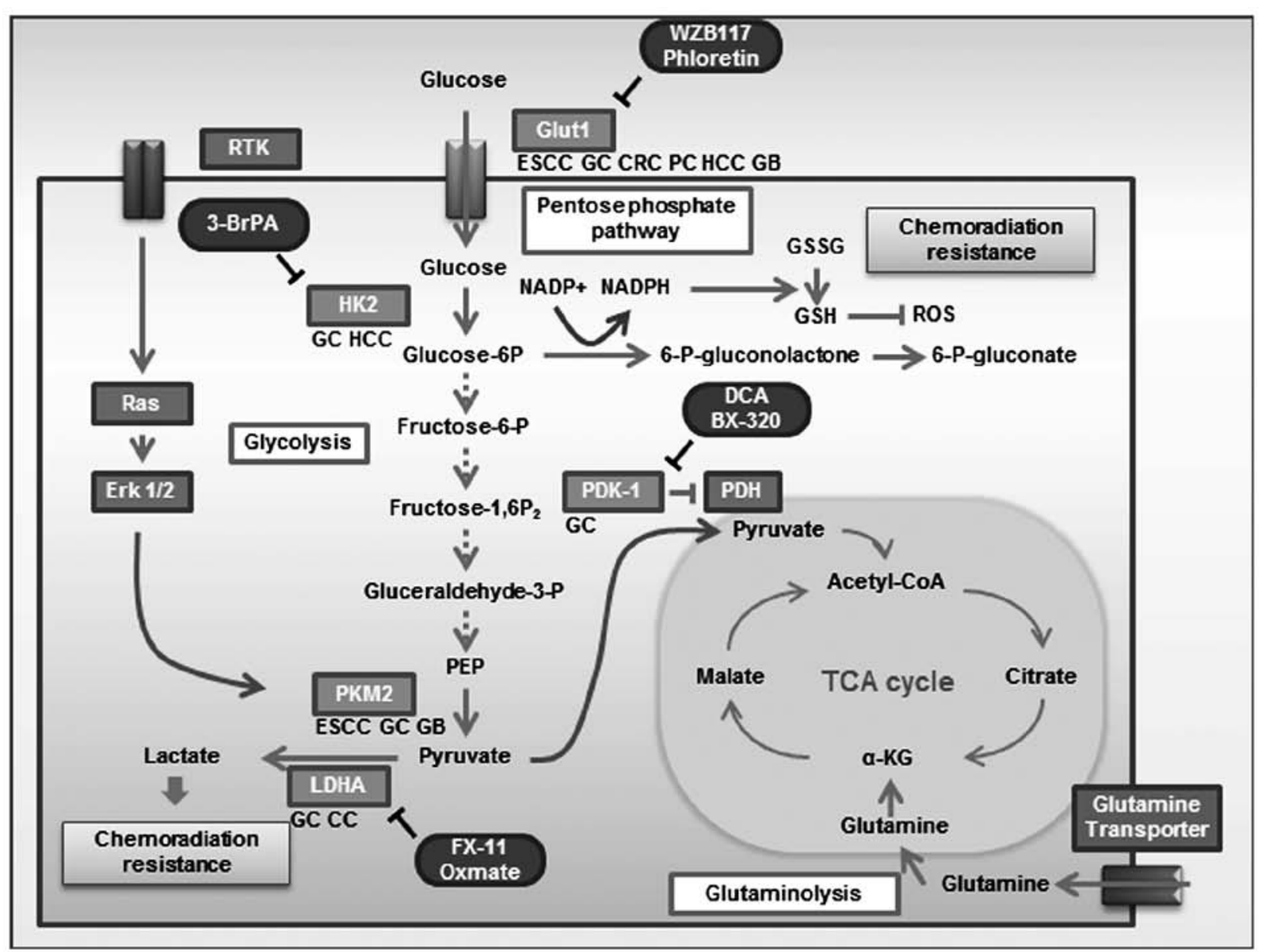

Figure 1. Glycolytic enzymes, metabolite transporters and small molecule inhibitors in the Warburg effect.

adaptation to hypoxia and regulates the expression of genes responsible for glucose metabolism, angiogenesis, and cell survival (11). Cellular HIF levels are regulated by both an oxygen-dependent pathway and an oxygen-independent pathway. HIF contains two key regulatory subunits, HIF1A and endothelial PAS domain protein 1 (EPAS1; HIF-2), and the genes encoding these proteins are overexpressed in human cancers $(12,13)$. Many studies have assessed the significance of HIF-1A positive expression in the prediction of clinical outcome of gastrointestinal cancer. HIF-1A expression is associated with poor prognosis in esophageal squamous cell carcinoma (ESCC) $(14,15)$, gastric cancer $(16,17)$, colorectal cancer (CRC) (18) and hepatocellular carcinoma (HCC) (19). Low expression of HIF1A may be associated with a favorable effect of 5-FU-based adjuvant chemotherapy in gastric cancer patients $(20,21)$. HIF-2A is associated with poor survival in gastric cancer patients (22) but not CRC patients $(18,23)$.

The $c-M y c$ oncogene, a member of the MYC family, encodes the transcription factor c-Myc and is upregulated in many human cancers, linking altered cellular metabolism to tumorigenesis (24). MYC gene expressions are often elevated or deregulated in human neoplasms, and c-Myc seems to be at the crossroads of several important pathways and processes involved in carcinogenesis. $M Y C$ deregulation due to gene amplification (25), chromosomal translocation or insertion (26), mutations (27), and epigenetic modifications (28) has been reported in different types of cancers. The number of studies of MYC expression as detected by immunohistochemistry (IHC) is less than that of HIF1A. c-Myc overexpression and promoter hypomethylation may have a role in the gastric carcinogenesis process and $c-M y c$ deregulation was associated mainly with poor prognosis (29). $c$-Myc expression detected by IHC was associated with poor prognosis in pancreatic cancer (30), but its expression was not associated with poor prognosis in CRC patients $(18,23)$ (Table I).

\section{Glucose transporters (Gluts)}

Glut1 is composed of 492 amino acid residues and possesses a single site of N-linked glycosylation at N45 (31). Multiple glucose transporter-like proteins have been identified and characterized (32) with sequence similarity to Glut1, and these genes appear to belong to the family of solute carriers $2 \mathrm{~A}$ (SLC2A, protein symbol Glut). The 14 Gluts are categorized into three classes based on sequence similarity: Class 1 (Gluts 1-4 and 14), Class 2 (Gluts 5, 7,9 and 11), and Class 3 (Gluts 6, $8,10,12$, and HMIT) (32). Glut families were evaluated with the GEO data set in silico (http://www.ncbi.nlm.nih.gov/gds/). Glut1 mRNA levels were remarkably upregulated in tumor lesions compared with normal lesions in CRC (GDS 4382), ESCC (GDS 3838) and pancreatic cancer (GDS 4336) (Table II). Several studies have been published on Glut family members, especially Glut3 (33-35), but Glut1 has been the main focus of investigation. A previous study evaluating Glut1 
Table I. Impact of HIF and MYC on cancer prognosis and correlation with clinicopathological features.

\begin{tabular}{lllllll}
\hline & \multicolumn{2}{c}{ Total } & & & Prognosis \\
\hline Organ & $\mathrm{N}$ & $\%$ & Cut-offs & $\begin{array}{c}\text { Expression correlated with: } \\
\text { (condition) }\end{array}$ & Univariate & Multivariate \\
\hline
\end{tabular}

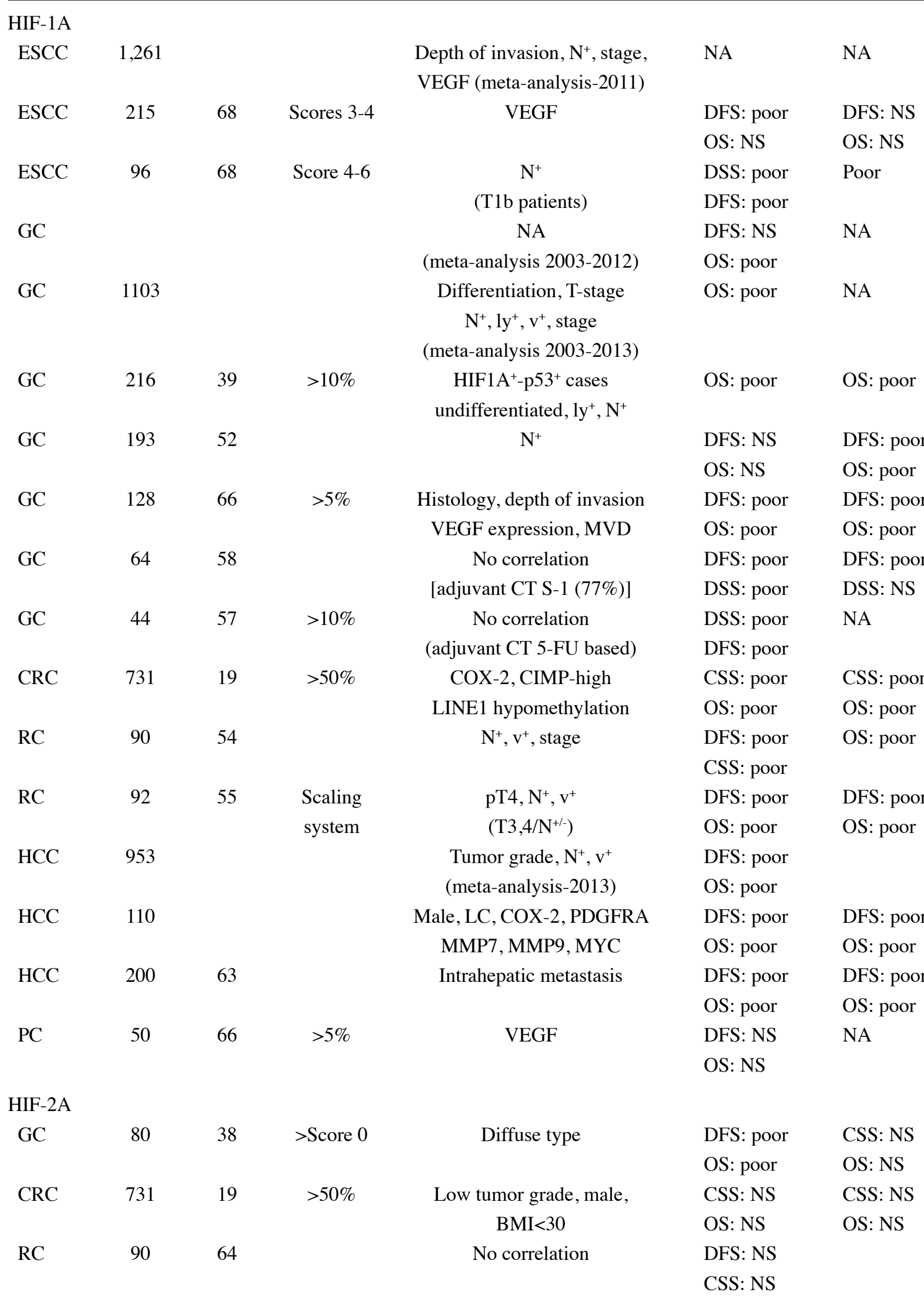


Table I. Continued.

\begin{tabular}{|c|c|c|c|c|c|c|c|}
\hline \multicolumn{4}{|c|}{ Total } & \multirow[b]{2}{*}{$\begin{array}{l}\text { Expression correlated with: } \\
\text { (condition) }\end{array}$} & \multicolumn{2}{|c|}{ Prognosis } & \multirow[b]{2}{*}{ (Ref.) } \\
\hline Organ & $\mathrm{N}$ & $\%$ & Cut-offs & & Univariate & Multivariate & \\
\hline \multicolumn{8}{|l|}{ MYC } \\
\hline $\mathrm{GC}$ & 125 & 77 & $>10 \%$ & $\begin{array}{l}\text { Intestinal-type, late-onset } \\
\text { deeper tumor extension, } \mathrm{M}^{+}\end{array}$ & NA & $\mathrm{NA}$ & (29) \\
\hline $\mathrm{PC}$ & 70 & 52 & Score 5-9 & Perineural invasion, stage & OS: poor & OS: poor & (30) \\
\hline $\mathrm{CRC}$ & 731 & 19 & $>50 \%$ & $\begin{array}{l}\text { Low tumor grade } \\
\text { male, } \mathrm{BMI}<30\end{array}$ & $\begin{array}{l}\text { CSS: NS } \\
\text { OS: NS }\end{array}$ & $\begin{array}{l}\text { CSS: NS } \\
\text { OS: NS }\end{array}$ & (18) \\
\hline $\mathrm{RC}$ & 90 & 64 & & No correlation & $\begin{array}{l}\text { DFS: NS } \\
\text { CSS: NS }\end{array}$ & & (23) \\
\hline
\end{tabular}

ESCC, esophageal squamous cell carcinoma; GC, gastric cancer; CRC, colorectal cancer; RC, rectal cancer; HCC, hepatocellular carcinoma; PC, pancreatic cancer; NA, no assessment; NS, not significant.

Table II. Overexpression of metabolite transporters and glycolytic enzymes in the Warburg effect.

\begin{tabular}{|c|c|c|c|c|c|c|c|c|c|}
\hline & \multicolumn{3}{|c|}{$\begin{array}{c}\text { Colorectal cancer }(\mathrm{N}=17) \\
\text { GDS4382 }\end{array}$} & \multicolumn{3}{|c|}{$\begin{array}{l}\text { ESCC }(\mathrm{N}=17) \\
\text { GDS3838 }\end{array}$} & \multicolumn{3}{|c|}{$\begin{array}{c}\text { Panctreatic cancer }(\mathrm{N}=45) \\
\text { GDS4336 }\end{array}$} \\
\hline & $\begin{array}{r}\mathrm{T} / \mathrm{N} \\
\text { ratio }\end{array}$ & $95 \%$ CI & P-value & $\begin{array}{r}\mathrm{T} / \mathrm{N} \\
\text { ratio }\end{array}$ & $95 \% \mathrm{CI}$ & P-value & $\begin{array}{l}\mathrm{T} / \mathrm{N} \\
\text { ratio }\end{array}$ & $95 \% \mathrm{CI}$ & P-value \\
\hline Glut1 & 1.90 & $(1.16-3.09)$ & 0.01 & 2.44 & $(1.78-3.34)$ & $<0.001$ & 3.58 & $(2.74-4.67)$ & $<0.001$ \\
\hline Glut2 & 0.92 & $(0.87-0.98)$ & 0.01 & 0.97 & $(0.93-1.01)$ & NS & 0.60 & $(0.46-0.80)$ & $<0.001$ \\
\hline Glut3 & 1.55 & $(0.72-3.31)$ & NS & 1.96 & $(1.23-3.13)$ & 0.01 & 1.54 & $(1.18-2.01)$ & $<0.001$ \\
\hline Glut4 & 1.18 & $(0.99-1.40)$ & NS & 0.97 & $(0.83-1.13)$ & NS & 0.89 & $(0.83-0.97)$ & 0.01 \\
\hline Glut5 & 0.52 & $(0.37-0.72)$ & $<0.001$ & 1.08 & $(0.80-1.44)$ & NS & 1.10 & $(0.91-1.31)$ & NS \\
\hline Glut6 & 0.84 & $(0.71-1.00)$ & 0.05 & 1.31 & $(1.12-1.54)$ & $<0.001$ & 0.95 & $(0.88-1.02)$ & NS \\
\hline Glut8 & 0.59 & $(0.10-3.60)$ & NS & 1.17 & $(1.00-1.36)$ & 0.04 & 0.93 & $(0.88-0.98)$ & 0.01 \\
\hline Glut9 & 1.13 & $(1.01-1.26)$ & 0.03 & 1.21 & $(1.01-1.45)$ & 0.04 & 1.07 & $(0.98-1.17)$ & NS \\
\hline Glut10 & 0.65 & $(0.35-1.19)$ & NS & 0.89 & $(0.66-1.18)$ & NS & 1.13 & $(1.02-1.25)$ & 0.02 \\
\hline Glut11 & 1.33 & $(0.96-1.85)$ & NS & 0.96 & $(0.88-1.05)$ & NS & 0.85 & $(0.78-0.93)$ & $<0.001$ \\
\hline Glut14 & 1.72 & $(1.08-2.72)$ & 0.03 & 1.45 & $(1.04-2.02)$ & 0.03 & 1.10 & $(0.98-1.23)$ & NS \\
\hline HK2 & 0.46 & $(0.26-0.79)$ & 0.009 & 1.53 & $(1.16-2.03)$ & 0.005 & 2.55 & $(1.97-3.30)$ & $<0.001$ \\
\hline LDHA & 1.05 & $(0.92-1.19)$ & NS & 0.92 & $(0.78-1.10)$ & NS & 1.89 & $(1.57-2.28)$ & $<0.001$ \\
\hline PMK2 & 0.80 & $(0.65-0.98)$ & 0.033 & 1.41 & $(1.02-1.95)$ & 0.04 & 2.03 & $(1.72-2.40)$ & $<0.001$ \\
\hline PDK1 & 1.18 & $(0.85-1.63)$ & NS & 1.37 & $(1.08-1.74)$ & 0.012 & 1.38 & $(1.18-1.61)$ & $<0.001$ \\
\hline
\end{tabular}

by IHC in tissue microarray slides comprising 1,955 samples detected Glut1 positivity in $47 \%$ prostate adenocarcinomas, $29 \%$ thyroid cancer, $10 \%$ gastric cancer, $5 \%$ breast adenocarcinomas, $36 \%$ head and neck SCC, $42 \%$ uterine cervix SCC, $18.6 \%$ glioblastomas and $9.4 \%$ retinoblastomas (36).

Glut1 is transcriptionally regulated by c-Myc (24) and HIF1A (37). A recent study demonstrated that Glut1 was one of three genes consistently upregulated in cells with KRAS or BRAF mutations (38). Glut1 expression in CRC cells was positively correlated with FDG accumulation and KRAS/BRAF mutation (39). EGFR and ERK1/2 correlate with levels of PKM2 Ser 37 phosphorylation, and nuclear PKM2 induces c-Myc expression, resulting in the upregulation of Glut1 (40). In a recent study using xenografts, overexpression of Glut1 in a mammary tumor cell lines with low levels of endogenous Glut1 results from both a decrease in apoptosis and an increase in proliferation (41).

Glut1 expression is generally absent in normal tissue, but in multiple gastrointestinal cancer cell types, Glut1 expression is remarkably enhanced. Glut1 positivity is associated with poor 
prognosis in diverse gastrointestinal cancers, $\operatorname{ESCC}(15,42,43)$, gastric cancer $(44,45)$, CRC $(46,47)$, pancreatic cancer, HCC (48), and gallbladder cancer $(49,50)$ (Table III).

Glut1 expression has the potential to serve as a biomarker for cancer. Anticancer therapies, such as radiation and several chemotherapeutic drugs, induce oxidative stress in targeted cells. Reactive oxygen species (ROS) are required for the fixation of radiation-induced DNA damage (51). Therefore, an accumulation of antioxidants (e.g., lactate) may induce or enhance resistance to radiation and may cause chemoresistance (52). Glut1 positivity was associated with tumor regression grade (TRG) and may be a useful predictive marker of response to chemoradiotherapy in rectal cancer $(47,53)$.

Phloretin, a natural product found in apples and pears with Glut inhibitory activity, exerts antitumor effects in HCC and color cancer cell lines $(54,55)$. The WZB117 small molecule inhibitor of Glut1 was effective in inhibiting cancer cell growth both in vitro and in vivo (56) (Table IV).

\section{Glycolytic enzymes (HK2, PKM2, PDK1 and LDHA)}

Hexokinases catalyze the phosphorylation of glucose to glucose-6-phosphate. This is the first and rate-limiting step in glucose metabolism. HK2 is one of four members of the hexokinase family. The four isoenzymes (HK1, HK2, HK3, and glucokinase) are structurally similar, but only HK1 and HK2 are functionally similar. HK2, but not HK1, is overexpressed in several cancer types compared with normal tissue. HK2 localizes to the outer membrane of the mitochondria and is the major hexokinase isoform expressed in cancer cells (57). High expression of HK2 confers a poor prognosis in HCC and gastric cancer (Table II), and HK2 positivity was associated with poor differentiation and advanced stage in $\mathrm{HCC}(58,59)$. Tumor differentiation in HCC correlated with FDG uptake (60), and the cellular retention of FDG may be mediated by HK2 (58).

The widely used 3-bromopyruvate (3-BrPA) (61) depletes cellular ATP. A previous study showed that $3-\mathrm{BrPA}$ inhibits HK2 expression and exhibits anti-proliferative effects combined with daunorubicin in CRC cell lines (54) and combined with protein disulfide isomerase in HCC cell lines in vivo (55).

Pyruvate kinase (PK) is a glycolytic enzyme that catalyzes a reaction generating pyruvate and ATP from phosphoenolpyruvate (PEP) and ADP. Four isoforms of PK (L, R, M1, and M2) have been identified in mammals. Splicing of PKM is controlled by splicing repressors, and the expression of the repressors is upregulated by c-Myc oncoprotein $(62,63)$. M2 is expressed in embryonic cells, adult stem cells, and cancer cells and is necessary for aerobic glycolysis. This metabolic phenotype provides a selective growth advantage for tumor cells in vivo $(64,65)$. PKM2 expression is associated with poor prognosis in ESCC, gallbladder cancer and signet ring cell carcinoma of gastric cancer (Table III). Small molecule inhibitors that selectively target PKM2 have been identified, suggesting that inhibition of PKM2 could be synergistic with other targeted therapies, including gefitinib. However, small molecule activation of PKM2 that promotes PKM2 tetramer formation interferes with anabolic metabolism and suppresses tumorigenesis (66). Mutation of the ERK-phosphorylation site
S37 in PKM2 blocked translocation of PKM2 to the nucleus (40), suggesting that PKM2 moves into the nucleus as a monomer. Tumor cells have multiple ways to regulate PKM2 that are favorable to cell growth and survival, including PKM2 expression, localization, post-translational modification, and allosteric regulation. PKM2 also regulates non-metabolic functions as a transcriptional coactivator and protein kinase. PKM2 is considered an attractive target for cancer treatment (67). Further studies are needed before inhibitors and activators of PKM2 can be used as therapeutic interventions (68).

PDK regulates the mitochondrial gatekeeper pyruvate dehydrogenase (PDH), which links glycolysis to the TCA cycle by reversible phosphorylation. Phosphorylation of PDH by PDK inhibits the action of PDH and halts pyruvate use in the TCA cycle (69). Four PDK isoforms have been verified in human tissue, and the expressions of the isoforms are organ specific. PDK-1 positivity was associated with poor prognosis in gastric cancer (70), but expression of PDK-1 was decreased in colon cancer compared with normal tissue. PDK-3 expression was detected in colon cancer, and PDK-3 positivity was associated with poor prognosis (71). Several studies reported the relationship between PDK positivity and prognosis in gastrointestinal cancer, but the clinical significance of PDK expression has remained unclear. Many small molecule PDK-1 inhibitors have been identified (72). DCA, a PDK-1 inhibitor, reduced lactate production and increased responsiveness to 5-FU in MKN45 cells (70) and CRC cell lines (73). DCA treatment exerts anti-proliferative effects and sorafenib resistance in HCC cell lines in vivo (74).

Lactate dehydrogenase is a tetrameric enzyme comprising two major subunits, A and/or B, resulting in five isozymes (A4, $\mathrm{A} 3 \mathrm{~B} 1, \mathrm{~A} 2 \mathrm{~B} 2, \mathrm{~A} 1 \mathrm{~B} 3$ and $\mathrm{B} 4)$ that can catalyze the forward and backward conversion of pyruvate to lactate. LDHA (LDH-5, MLDH, or A4), which is the predominant form in skeletal muscle, kinetically favors the conversion of pyruvate to lactate, controlling the conversion of pyruvate to lactate in the cellular glycolytic process (75). Many human cancers have higher LDHA levels than normal tissues (76). LDHA is specifically phosphorylated at Y10 in various cancer cell lines, head and neck SCC, lung cancer, breast cancer, and prostate cancer cells and by diverse oncogenic tyrosine kinases, including FGFR1, ABL, JAK2, and FLT3 (77).

LDHA reduction can suppress the tumorigenicity of intestinal-type gastric cancer (ITGC) cells, colon cancer (78) and HCC (79). A previous study of 661 ITGC specimens showed that low LDHA expression exhibited better overall survival than high LDHA expression (80).

Similar to small interfering RNA (siRNA) reduction of LDHA expression, the FX11 small molecule inhibitor for LDHA could increase cellular oxygen consumption, increase ROS production, and induce cell death that could be partially rescued by the antioxidant NAC in a lymphoma cell line (81). Oxmate, a lactate dehydrogenase inhibitor, combined with phenformin exhibited cytotoxic effects in diverse cancer cell lines, including colon cancer (82).

\section{Conclusions and future perspectives}

This review describes the significance of protein expression of the transcriptional factors, glycolytic enzymes and metabo- 
Table III. Impact of Glut1 and glycolytic enzymes on prognosis and correlation with clinicopathological features.

\begin{tabular}{ccccccc}
\hline & \multicolumn{2}{c}{ Total } & & & Prognosis \\
\hline Organ & $\mathrm{N}$ & $\%$ & Cut-offs & $\begin{array}{c}\text { Expression correlated with: } \\
\text { (condition) }\end{array}$ & Univariate & Multivariate \\
(Ref.)
\end{tabular}

Glut1

\begin{tabular}{|c|c|c|c|}
\hline ESCC & 145 & 43 & $>50 \%$ \\
\hline ESCC & 63 & 48 & $>30 \%$ \\
\hline ESCC & 96 & 71 & Score 4-6 \\
\hline GC & 617 & 30 & $>1 \%$ \\
\hline GC & 152 & 24 & $>30 \%$ \\
\hline GC & 193 & 43 & \\
\hline CRC & 163 & & \\
\hline CRC & 112 & 18 & $>50 \%$ \\
\hline $\mathrm{RC}$ & 46 & 48 & $>10 \%$ \\
\hline $\mathrm{PC}$ & 94 & 75 & $>50 \%$ \\
\hline $\mathrm{HCC}$ & 63 & 37 & $\begin{array}{c}\text { Scoring } \\
\geq \text { Score } 1\end{array}$ \\
\hline GB & 56 & 34 & $>50 \%$ \\
\hline GB & 71 & 52 & \\
\hline
\end{tabular}

HK2

$\begin{array}{cccc}\text { GC } & 257 & 17 & >30 \% \\ \text { GC } & 152 & 5 & >30 \% \\ \text { GC } & 188 & 21 & \\ \text { HCC } & 157 & 15 & \text { High } \\ & & & \text { mod. }\end{array}$

$\begin{array}{lll}\mathrm{HCC} & 97 \quad 56\end{array}$

mod.

HCC $\quad 31 \quad 81$

$$
\begin{aligned}
& \text { pT3, } \mathrm{v}^{+} \text {MVD } \\
& \text { (no preoperative treatment) } \\
& \text { No correlation } \\
& \text { (curative operation) }
\end{aligned}
$$

$$
\mathrm{N}^{+}
$$$$
\text { (T1b patients) }
$$

pap>por or tub, T-stage

$\mathrm{N}^{+}, \mathrm{ly}^{+}, \mathrm{v}^{+}, \mathrm{H}^{+}$, stage

T2-T4, $\mathrm{N}^{+}$, diffuse type

Age $>65, \mathrm{~T} 2-\mathrm{T} 4, \mathrm{~N}^{+}$, stage, intestinal type

Poorly differentied higher in stage III + IV

$$
\mathrm{N}^{+} \text {, }
$$

No correlation

Historogical grade, MIB1 (ductal AC)

$$
\text { SUV, TNR, Ki67LI }
$$

Perinecrotic areas

Histologic tumor type

$$
\text { tumor stage }
$$

$$
\text { No correlation }
$$

No correlation

Size, lower differentiation, stage, HIF1A

Moderately and poorly, advanced stage

$$
\text { No correlation }
$$

Moderately and poorly differentiated

PKM2

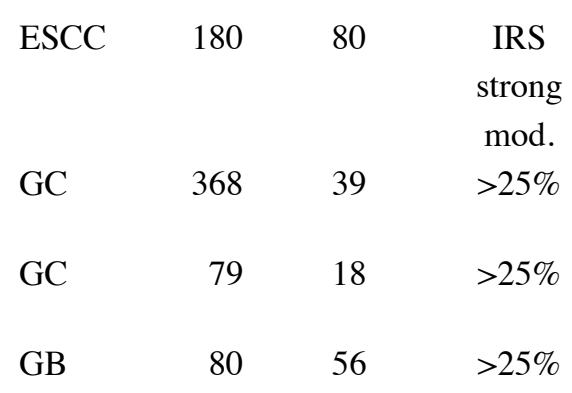

\section{Differntiation poorly}

tumor size, stage

Age, t-stage, well differentiatied

Subgroup analysis above study (signet cell)

Differntiation poorly,

\section{DFS: poor}

CSS: poor

OS: poor

DFS: NS

CCS: NS

OS: NS

DFS: poor

NS

CSS: poor

OS: poor

OS: poor

DFS: NS

DFS: NS

OS: NS

OS: NS

OS: poor

OS: NS

OS: poor

OS: poor

CSS: poor

CSS: poor

DFS: $p=0.066$

NA

OS: poor

OS: poor

DFS: poor

NA

OS: poor

OS: poor

NA

OS: poor

DFS: NS

DFS: NS

OS: NS

OS: NS

DFS: NS

DFS: NS

OS: NS

OS: NS

OS: poor

OS: poor

OS: poor

OS: poor

OS: poor

NA

OS: NS

OS: NS tumor size, stage, $\mathrm{N}^{+}$
OS: poor $\quad$ OS: poor

OS: NS

OS: NS

OS: poor

OS: poor

OS: poor

OS: poor 
Table III. Continued.

\begin{tabular}{|c|c|c|c|c|c|c|c|}
\hline \multicolumn{4}{|c|}{ Total } & \multirow[b]{2}{*}{$\begin{array}{l}\text { Expression correlated with: } \\
\text { (condition) }\end{array}$} & \multicolumn{2}{|c|}{ Prognosis } & \multirow[b]{2}{*}{ (Ref.) } \\
\hline Organ & $\mathrm{N}$ & $\%$ & Cut-offs & & Univariate & Multivariate & \\
\hline \multicolumn{8}{|c|}{ PDK-1 } \\
\hline GC & 152 & 12 & $>30 \%$ & $\begin{array}{c}\mathrm{T} 3-\mathrm{T} 4, \mathrm{~N}^{+} \text {, tumor size } \\
\text { HIF-1A }\end{array}$ & $\begin{array}{l}\text { DFS: poor } \\
\text { OS: poor }\end{array}$ & $\begin{array}{l}\text { DFS: poor } \\
\text { OS: poor }\end{array}$ & $(70)$ \\
\hline $\mathrm{CC}$ & 74 & - & $\begin{array}{c}\text { Blot } \\
\text { density }\end{array}$ & $\begin{array}{c}\text { Expression PDK1 } \\
\text { deceased in cancer tissue }\end{array}$ & NA & NA & $(70)$ \\
\hline \multicolumn{8}{|c|}{ PDK-3 } \\
\hline $\mathrm{CC}$ & 206 & 86 & Stain $^{+}$ & Stage, HIF-1A & $\begin{array}{l}\text { DFS: poor } \\
\text { OS: poor }\end{array}$ & NA & $(71)$ \\
\hline \multicolumn{8}{|c|}{ LDH-5 } \\
\hline $\mathrm{GC}$ & 94 & 62 & & $\begin{array}{c}\text { Advanced tumor, } \mathrm{v}^{+} \\
\text {HIF-1A, VEGF, COC-2 }\end{array}$ & $\begin{array}{l}\text { DFS: poor } \\
\text { OS: poor }\end{array}$ & NA & $(98)$ \\
\hline $\mathrm{CC}$ & 128 & 77 & & $\begin{array}{l}\text { Poor differentiation } \\
\text { HIF1A, pKDR }\end{array}$ & $\begin{array}{l}\text { DFS: poor } \\
\text { OS: poor }\end{array}$ & NA & $(78)$ \\
\hline
\end{tabular}

Table IV. Anti-proliferative effect of inhibitors of metabolite transporters and glycolytic enzymes.

\begin{tabular}{|c|c|c|c|c|c|c|}
\hline Target & Inhibitor & $\begin{array}{l}\text { Cancer type } \\
\text { (cell lines) }\end{array}$ & $\begin{array}{l}\text { Dose } \\
\text { in vitro }\end{array}$ & $\begin{array}{l}\text { Dose } \\
\text { in vivo }\end{array}$ & $\begin{array}{l}\text { Combination or } \\
\text { drug resistance }\end{array}$ & (Ref.) \\
\hline \multirow[t]{2}{*}{ Glut1 } & WZB117 & LC (A549) & $10 \mu \mathrm{M}$ & 10 mg/kg (i.p.) daily & NA & $(56)$ \\
\hline & Phloretin & CRC (SW620) & $50 \mu \mathrm{M}$ & NA & DNR & $(54)$ \\
\hline \multirow[t]{2}{*}{ Glut2 } & Phloretin & HCC (HepG2) & $200 \mu \mathrm{M}$ & 10 mg/kg (i.p.) & DNR & $(55)$ \\
\hline & & & & 3 times per week & & \\
\hline \multirow[t]{2}{*}{ HK-2 } & 3-BrPA & HCC (Huh-7) & $100 \mu \mathrm{M}$ & 1 mg/kg (i.p.) & PDI & (99) \\
\hline & 3-BrPA & CRC (HCT116, HT29) & $30 \mu \mathrm{M}$ & NA & Ox-resistant cells & $(100)$ \\
\hline PKM-2 & Compound 3 & $\begin{array}{l}\text { LC (H1299), } \\
\text { hematopoetic (FL5.12) }\end{array}$ & $30 \mu \mathrm{M}$ & NA & Gefitinib & $(101)$ \\
\hline \multirow[t]{5}{*}{ PDK } & $\mathrm{DCA}$ & HCC (Huh-7) & $30 \mathrm{mM}$ & $\begin{array}{l}100 \mathrm{mg} \text { per } \mathrm{kg} \text { bw } \\
\text { per day }\end{array}$ & $\begin{array}{c}\text { Sorafinib-resistant } \\
\text { cells }\end{array}$ & (74) \\
\hline & $\mathrm{DCA}$ & GC (MKN45, AGS) & $20 \mathrm{mM}$ & NA & $5-\mathrm{FU}$ & $(70)$ \\
\hline & $\mathrm{DCA}$ & $\begin{array}{l}\text { CRC (SW620, LoVo, } \\
\text { LS174t, HT29) }\end{array}$ & $10 \mathrm{mM}$ & NA & $5-\mathrm{FU}$ & $(73)$ \\
\hline & $\mathrm{BX}-320$ & CRC (HCT116) & $0.28 \mu \mathrm{M}$ & NA & NA & $(102)$ \\
\hline & & $\mathrm{PC}(\mathrm{MiaPaCa})$ & $0.33 \mu \mathrm{M}$ & & & \\
\hline \multirow[t]{2}{*}{ LDHA } & FX11 & Lymphoma (P493) & $9 \mu \mathrm{M}$ & $42 \mu \mathrm{g}$ (i.p.) daily & FK866 & $(81)$ \\
\hline & Oxmate & CRC (CT26) & $9 \mu \mathrm{M}$ & NA & Phenformin & $(82)$ \\
\hline
\end{tabular}


lite transporters involved in the Warburg effect as potential biomarkers. The functional and therapeutic importance of the Warburg effect is increasingly recognized, and glycolysis has become a target of anticancer strategies. Novel small molecule inhibitors targeting enzymes that function in the Warburg effect have been developed and anti-proliferative effects on diverse cancer cells have been demonstrated. The gene expressions of molecular factors involved in the Warburg effect are associated with poor prognosis and may be associated with chemoradiotherapy resistance in gastrointestinal cancers. Novel small molecules exert anti-proliferative effects and may reduce chemoradiotherapy resistance in gastrointestinal cancer, breast cancer (83) and lung cancer (56) (Table IV).

Future studies should examine whether inhibitors of glycolytic enzymes and metabolite transporters are useful in gastrointestinal cancer and evaluate adverse effect and feasibility for clinical practice. Furthermore, validation of imaging techniques, which establish glucose metabolism and predict response to drugs, is required for optimal patient selection.

\section{References}

1. Warburg O: On respiratory impairment in cancer cells Science 124: 269-270, 1956.

2. Younes M, Lechago LV, Somoano JR, Mosharaf M and Lechago J: Wide expression of the human erythrocyte glucose transporter Glut1 in human cancers. Cancer Res 56: 1164-1167, 1996.

3. Warburg O: On the origin of cancer cells. Science 123: 309-314, 1956.

4. Plathow $\mathrm{C}$ and Weber WA: Tumor cell metabolism imaging. J Nucl Med 49 (Suppl 2): S43-S63, 2008.

5. Plas DR and Thompson CB: Akt-dependent transformation: there is more to growth than just surviving. Oncogene 24: 7435-7442, 2005.

6. Elstrom RL, Bauer DE, Buzzai M, et al: Akt stimulates aerobic glycolysis in cancer cells. Cancer Res 64: 3892-3899, 2004

7. Vousden KH and Ryan KM: p53 and metabolism. Nat Rev Cancer 9: 691-700, 2009.

8. Stambolic V, MacPherson D, Sas D, et al: Regulation of PTEN transcription by p53. Mol Cell 8: 317-325, 2001.

9. Jones RG, Plas DR, Kubek S, et al: AMP-activated protein kinase induces a p53-dependent metabolic checkpoint. Mol Cell 18: 283-293, 2005.

10. Shackelford DB and Shaw RJ: The LKB1-AMPK pathway: metabolism and growth control in tumour suppression. Nat Rev Cancer 9: 563-575, 2009.

11. Lu H, Forbes RA and Verma A: Hypoxia-inducible factor 1 activation by aerobic glycolysis implicates the Warburg effect in carcinogenesis. J Biol Chem 277: 23111-23115, 2002.

12. Zhong H, De Marzo AM, Laughner E, et al: Overexpression of hypoxia-inducible factor 1alpha in common human cancers and their metastases. Cancer Res 59: 5830-5835, 1999.

13. Talks KL, Turley H, Gatter KC, et al: The expression and distribution of the hypoxia-inducible factors HIF-1alpha and HIF-2alpha in normal human tissues, cancers, and tumor-associated macrophages. Am J Pathol 157: 411-421, 2000.

14. Matsuyama $\mathrm{T}$, Nakanishi $\mathrm{K}$, Hayashi $\mathrm{T}$, et al: Expression of hypoxia-inducible factor-1alpha in esophageal squamous cell carcinoma. Cancer Sci 96: 176-182, 2005.

15. Ogane N, Yasuda M, Shimizu M, et al: Clinicopathological implications of expressions of hypoxia-related molecules in esophageal superficial squamous cell carcinoma. Ann Diagn Pathol 14: 23-29, 2010.

16. Zhang ZG,Zhang QN, Wang XH and Tian JH: Hypoxia-inducible factor 1 alpha (HIF-lalpha) as a prognostic indicator in patients with gastric tumors: a meta-analysis. Asian Pac J Cancer Prev 14 4195-4198, 2013

17. Lin S, Ma R, Zheng XY, et al: Meta-analysis of immunohistochemical expression of hypoxia inducible factor-1alpha as a prognostic role in gastric cancer. World J Gastroenterol 20: $1107-1113,2014$
18. Baba Y, Nosho K, Shima K, et al: HIF1A overexpression is associated with poor prognosis in a cohort of 731 colorectal cancers. Am J Pathol 176: 2292-2301, 2010.

19. Zheng SS, Chen XH, Yin X and Zhang BH: Prognostic significance of HIF-1alpha expression in hepatocellular carcinoma: a meta-analysis. PloS One 8: e65753, 2013.

20. Nakamura J, Kitajima Y, Kai K, et al: Hypoxia-inducible factorlalpha expression predicts the response to 5-fluorouracil-based adjuvant chemotherapy in advanced gastric cancer. Oncol Rep 22: 693-699, 2009.

21. Nakamura J, Kitajima Y, Kai K, et al: HIF-1alpha is an unfavorable determinant of relapse in gastric cancer patients who underwent curative surgery followed by adjuvant 5 -FU chemotherapy. Int J Cancer 127: 1158-1171, 2010.

22. Griffiths EA, Pritchard SA, McGrath SM, et al: Hypoxiaassociated markers in gastric carcinogenesis and HIF-2alpha in gastric and gastro-oesophageal cancer prognosis. Br J Cancer 98: 965-973, 2008.

23. Rasheed S, Harris AL, Tekkis PP, et al: Hypoxia-inducible factor-1alpha and -2alpha are expressed in most rectal cancers but only hypoxia-inducible factor-1alpha is associated with prognosis. Br J Cancer 100: 1666-1673, 2009.

24. Dang CV, Le A and Gao P: MYC-induced cancer cell energy metabolism and therapeutic opportunities. Clin Cancer Res 15: 6479-6483, 2009.

25. Calcagno DQ, Leal MF, Assumpcao PP, Smith MA and Burbano RR: MYC and gastric adenocarcinoma carcinogenesis. World J Gastroenterol 14: 5962-5968, 2008.

26. Liu Y, Gong LP, Dong XL and Liu HG: Detection of C-MYC oncogene translocation and copy number change in the normaldysplasia-carcinoma sequence of the larynx by fluorescence in situ hybridization. Diagn Cytopathol 41: 515-519, 2013.

27. Tuupanen S, Yan J, Turunen M, et al: Characterization of the colorectal cancer-associated enhancer MYC-335 at 8q24: the role of rs67491583. Cancer Genet 205: 25-33, 2012.

28. Amente S, Lania L and Majello B: Epigenetic reprogramming of Myc target genes. Am J Cancer Res 1: 413-418, 2011.

29. de Souza CR, Leal MF, Calcagno DQ, et al: MYC deregulation in gastric cancer and its clinicopathological implications. PloS One 8: e64420, 2013.

30. He C, Jiang H, Geng S, et al: Expression and prognostic value of c-Myc and Fas (CD95/APO1) in patients with pancreatic cancer. Int J Clin Exp Pathol 7: 742-750, 2014.

31. Mueckler M, Caruso C, Baldwin SA, et al: Sequence and structure of a human glucose transporter. Science 229: 941-945, 1985.

32. Joost HG and Thorens B: The extended GLUT-family of sugar/ polyol transport facilitators: nomenclature, sequence characteristics, and potential function of its novel members (review). Mol Membr Biol 18: 247-256, 2001.

33. Younes M, Lechago LV, Somoano JR, Mosharaf $M$ and Lechago J: Immunohistochemical detection of Glut3 in human tumors and normal tissues. Anticancer Res 17: 2747-2750, 1997.

34. Ayala FR, Rocha RM, Carvalho KC, et al: GLUT1 and GLUT3 as potential prognostic markers for oral squamous cell carcinoma. Molecules 15: 2374-2387, 2010.

35. Fonteyne P, Casneuf V, Pauwels P, et al: Expression of hexokinases and glucose transporters in treated and untreated oesophageal adenocarcinoma. Histol Histopathol 24: 971-977, 2009.

36. Carvalho KC, Cunha IW, Rocha RM, et al: GLUT1 expression in malignant tumors and its use as an immunodiagnostic marker. Clinics (Sao Paulo) 66: 965-972, 2011.

37. Griffiths EA, Pritchard SA, Welch IM, Price PM and West CM: Is the hypoxia-inducible factor pathway important in gastric cancer? Eur J Cancer 41: 2792-2805, 2005.

38. Yun J, Rago C, Cheong I, et al: Glucose deprivation contributes to the development of KRAS pathway mutations in tumor cells. Science 325: 1555-1559, 2009.

39. Kawada K, Nakamoto Y, Kawada M, et al: Relationship between ${ }^{18} \mathrm{~F}$-fluorodeoxyglucose accumulation and KRAS/BRAF mutations in colorectal cancer. Clin Cancer Res 18: 1696-1703, 2012.

40. Yang W, Zheng Y, Xia Y, et al: ERK1/2-dependent phosphorylation and nuclear translocation of PKM2 promotes the Warburg effect. Nat Cell Biol 14: 1295-1304, 2012.

41. Young CD, Lewis AS, Rudolph MC, et al: Modulation of glucose transporter 1 (GLUT1) expression levels alters mouse mammary tumor cell growth in vitro and in vivo. PloS One 6: e23205, 2011. 
42. Sawayama H, Ishimoto T, Watanabe M, et al: High expression of glucose transporter 1 on primary lesions of esophageal squamous cell carcinoma is associated with hematogenous recurrence. Ann Surg Oncol 21: 1756-1762, 2014.

43. Tohma T, Okazumi S, Makino H, et al: Overexpression of glucose transporter 1 in esophageal squamous cell carcinomas: a marker for poor prognosis. Dis Esophagus 18: 185-189, 2005.

44. Kawamura T, Kusakabe T, Sugino T, et al: Expression of glucose transporter-1 in human gastric carcinoma: association with tumor aggressiveness, metastasis, and patient survival. Cancer 92: 634-641, 2001

45. Jung JH, Im S, Jung ES and Kang CS: Clinicopathological implications of the expression of hypoxia-related proteins in gastric cancer. Int J Med Sci 10: 1217-1223, 2013.

46. Haber RS, Rathan A, Weiser KR, et al: GLUT1 glucose transporter expression in colorectal carcinoma: a marker for poor prognosis. Cancer 83: 34-40, 1998.

47. Korkeila E, Jaakkola PM, Syrjanen K, Pyrhonen S and Sundstrom J: Pronounced tumour regression after radiotherapy is associated with negative/weak glucose transporter-1 expression in rectal cancer. Anticancer Res 31: 311-315, 2011.

48. Kitamura K, Hatano E, Higashi T, et al: Proliferative activity in hepatocellular carcinoma is closely correlated with glucose metabolism but not angiogenesis. J Hepatol 55: 846-857, 2011.

49. Legan M, Tevzic S, Tolar A, Luzar B and Marolt VF: Glucose transporter-1 (GLUT-1) immunoreactivity in benign, premalignant and malignant lesions of the gallbladder. Pathol Oncol Res 17: 61-66, 2011 .

50. Kim YW, Park YK, Yoon TY and Lee SM: Expression of the GLUT1 glucose transporter in gallbladder carcinomas. Hepatogastroenterology 49: 907-911, 2002.

51. Sattler UG and Mueller-Klieser W: The anti-oxidant capacity of tumour glycolysis. Int J Radiat Biol 85: 963-971, 2009.

52. Hirschhaeuser F, Sattler UG and Mueller-Klieser W: Lactate: a metabolic key player in cancer. Cancer Res 71: 6921-6925, 2011

53. Brophy S, Sheehan KM, McNamara DA, Deasy J, BouchierHayes DJ and Kay EW: GLUT-1 expression and response to chemoradiotherapy in rectal cancer. Int J Cancer 125: 2778-2782, 2009.

54. Cao X, Fang L, Gibbs S, et al: Glucose uptake inhibitor sensitizes cancer cells to daunorubicin and overcomes drug resistance in hypoxia. Cancer Chemother Pharmacol 59: 495-505, 2007.

55. Wu CH, Ho YS, Tsai CY, et al: In vitro and in vivo study of phloretin-induced apoptosis in human liver cancer cells involving inhibition of type II glucose transporter. Int J Cancer 124: 2210-2219, 2009.

56. Liu Y, Cao Y, Zhang W, et al: A small-molecule inhibitor of glucose transporter 1 downregulates glycolysis, induces cell-cycle arrest, and inhibits cancer cell growth in vitro and in vivo. Mol Cancer Ther 11: 1672-1682, 2012.

57. Mathupala SP, Ko YH and Pedersen PL: Hexokinase-2 bound to mitochondria: cancer's stygian link to the 'Warburg Effect' and a pivotal target for effective therapy. Semin Cancer Biol 19: 17-24, 2009.

58. Kwee SA, Hernandez B, Chan O and Wong L: Choline kinase alpha and hexokinase-2 protein expression in hepatocellular carcinoma: association with survival. PloS One 7: e46591, 2012.

59. Paudyal B, Paudyal P, Oriuchi N, Tsushima Y, Nakajima T and Endo K: Clinical implication of glucose transport and metabolism evaluated by ${ }^{18} \mathrm{~F}-\mathrm{FDG}$ PET in hepatocellular carcinoma. Int J Oncol 33: 1047-1054, 2008

60. Seo S, Hatano E, Higashi T, et al: Fluorine-18 fluorodeoxyglucose positron emission tomography predicts tumor differentiation, P-glycoprotein expression, and outcome after resection in hepatocellular carcinoma. Clin Cancer Res 13: 427-433, 2007.

61. Ganapathy-Kanniappan S, Vali M, Kunjithapatham R, et al: 3-bromopyruvate: a new targeted antiglycolytic agent and a promise for cancer therapy. Curr Pharm Biotechnol 11: 510-517, 2010.

62. David CJ, Chen M, Assanah M, Canoll P and Manley JL: HnRNP proteins controlled by c-Myc deregulate pyruvate kinase mRNA splicing in cancer. Nature 463: 364-368, 2010.

63. Clower CV, Chatterjee D, Wang Z, Cantley LC, Vander Heiden MG and Krainer AR: The alternative splicing repressors hnRNP A1/A2 and PTB influence pyruvate kinase isoform expression and cell metabolism. Proc Natl Acad Sci USA 107: 1894-1899, 2010

64. Christofk HR, Vander Heiden MG, Harris MH, et al: The M2 splice isoform of pyruvate kinase is important for cancer metabolism and tumour growth. Nature 452: 230-233, 2008.
65. Christofk HR, Vander Heiden MG, Wu N, Asara JM and Cantley LC: Pyruvate kinase M2 is a phosphotyrosine-binding protein. Nature 452: 181-186, 2008

66. Anastasiou D, Yu Y, Israelsen WJ, et al: Pyruvate kinase M2 activators promote tetramer formation and suppress tumorigenesis. Nat Chem Biol 8: 839-847, 2012.

67. Yang $\mathrm{W}$ and $\mathrm{Lu} \mathrm{Z}$ : Regulation and function of pyruvate kinase M2 in cancer. Cancer Lett 339: 153-158, 2013.

68. Tamada M, Suematsu M and Saya H: Pyruvate kinase M2: multiple faces for conferring benefits on cancer cells. Clin Cancer Res 18: 5554-5561, 2012.

69. Kaplon J, Zheng L, Meissl K, et al: A key role for mitochondrial gatekeeper pyruvate dehydrogenase in oncogene-induced senescence. Nature 498: 109-112, 2013.

70. Hur H, Xuan Y, Kim YB, et al: Expression of pyruvate dehydrogenase kinase-1 in gastric cancer as a potential therapeutic target. Int J Oncol 42: 44-54, 2013.

71. Lu CW, Lin SC, Chien CW, et al: Overexpression of pyruvate dehydrogenase kinase 3 increases drug resistance and early recurrence in colon cancer. Am J Pathol 179: 1405-1414, 2011.

72. Peifer C and Alessi DR: Small-molecule inhibitors of PDK1. Chem Med Chem 3: 1810-1838, 2008.

73. Tong J, Xie G, He J, Li J, Pan F and Liang H: Synergistic antitumor effect of dichloroacetate in combination with 5-fluorouracil in colorectal cancer. J Biomed Biotechnol 2011: 740564, 2011.

74. Shen YC, Ou DL, Hsu C, et al: Activating oxidative phosphorylation by a pyruvate dehydrogenase kinase inhibitor overcomes sorafenib resistance of hepatocellular carcinoma. Br J Cancer 108: 72-81, 2013

75. Fantin VR, St-Pierre J and Leder P: Attenuation of LDH-A expression uncovers a link between glycolysis, mitochondrial physiology, and tumor maintenance. Cancer Cell 9: 425-434, 2006.

76. Goldman RD, Kaplan NO and Hall TC: Lactic dehydrogenase in human neoplastic tissues. Cancer Res 24: 389-399, 1964.

77. Fan J, Hitosugi T, Chung TW, et al: Tyrosine phosphorylation of lactate dehydrogenase A is important for NADH/NAD(+) redox homeostasis in cancer cells. Mol Cell Biol 31: 4938-4950, 2011.

78. Koukourakis MI, Giatromanolaki A, Sivridis E, Gatter KC and Harris AL: Lactate dehydrogenase 5 expression in operable colorectal cancer: strong association with survival and activated vascular endothelial growth factor pathway - a report of the Tumour Angiogenesis Research Group. J Clin Oncol 24: 4301-4308, 2006

79. Sheng SL, Liu JJ, Dai YH, Sun XG, Xiong XP and Huang G: Knockdown of lactate dehydrogenase A suppresses tumor growth and metastasis of human hepatocellular carcinoma. FEBS J 279: 3898-3910, 2012

80. Zhang Y, Zhang X, Wang X, et al: Inhibition of LDH-A by lentivirus-mediated small interfering RNA suppresses intestinaltype gastric cancer tumorigenicity through the downregulation of Oct4. Cancer Lett 321: 45-54, 2012.

81. Le A, Cooper CR, Gouw AM, et al: Inhibition of lactate dehydrogenase A induces oxidative stress and inhibits tumor progression. Proc Natl Acad Sci USA 107: 2037-2042, 2010.

82. Miskimins WK, Ahn HJ, Kim JY, Ryu S, Jung YS and Choi JY: Synergistic anti-cancer effect of phenformin and oxamate. PloS One 9: e85576, 2014

83. Zhou M, Zhao Y, Ding Y, et al: Warburg effect in chemosensitivity: targeting lactate dehydrogenase-A re-sensitizes taxol-resistant cancer cells to taxol. Mol Cancer 9: 33, 2010

84. Sumiyoshi Y, Kakeji Y, Egashira A, Mizokami K, Orita H and Maehara Y: Overexpression of hypoxia-inducible factor 1alpha and $\mathrm{p} 53$ is a marker for an unfavorable prognosis in gastric cancer. Clin Cancer Res 12: 5112-5117, 2006.

85. Isobe T, Aoyagi K, Koufuji K, et al: Clinicopathological significance of hypoxia-inducible factor-1 alpha (HIF-1alpha) expression in gastric cancer. Int J Clin Oncol 18: 293-304, 2013.

86. Theodoropoulos GE, Lazaris AC, Theodoropoulos VE, et al Hypoxia, angiogenesis and apoptosis markers in locally advanced rectal cancer. Int J Colorectal Dis 21: 248-257, 2006.

87. Dai CX, Gao Q, Qiu SJ, et al: Hypoxia-inducible factor-1 alpha, in association with inflammation, angiogenesis and MYC, is a critical prognostic factor in patients with HCC after surgery. BMC Cancer 9: 418, 2009.

88. Liu L, Zhu XD, Wang WQ, et al: Activation of beta-catenin by hypoxia in hepatocellular carcinoma contributes to enhanced metastatic potential and poor prognosis. Clin Cancer Res 16: 2740-2750, 2010 . 
89. Couvelard A, O'Toole D, Leek R, et al: Expression of hypoxiainducible factors is correlated with the presence of a fibrotic focus and angiogenesis in pancreatic ductal adenocarcinomas. Histopathology 46: 668-676, 2005.

90. Shen YM, Arbman G, Olsson B and Sun XF: Overexpression of GLUT1 in colorectal cancer is independently associated with poor prognosis. Int J Biol Markers 26: 166-172, 2011.

91. Pizzi S, Porzionato A, Pasquali C, et al: Glucose transporter-1 expression and prognostic significance in pancreatic carcinogenesis. Histol Histopathol 24: 175-185, 2009.

92. Rho M, Kim J, Jee CD, et al: Expression of type 2 hexokinase and mitochondria-related genes in gastric carcinoma tissues and cell lines. Anticancer Res 27: 251-258, 2007.

93. Qiu MZ, Han B, Luo HY, et al: Expressions of hypoxia-inducible factor-1alpha and hexokinase-II in gastric adenocarcinoma: the impact on prognosis and correlation to clinicopathologic features. Tumour Biol 32: 159-166, 2011.

94. Gong L, Cui Z, Chen P, Han H, Peng J and Leng X: Reduced survival of patients with hepatocellular carcinoma expressing hexokinase II. Med Oncol 29: 909-914, 2012.

95. Zhan C, Shi Y, Lu C and Wang Q: Pyruvate kinase M2 is highly correlated with the differentiation and the prognosis of esophageal squamous cell cancer. Dis Esophagus 26: 746-753, 2013.

96. Lim JY, Yoon SO, Seol SY, et al: Overexpression of the M2 isoform of pyruvate kinase is an adverse prognostic factor for signet ring cell gastric cancer. World J Gastroenterol 18: 4037-4043, 2012.
97. Li J, Yang Z, Zou Q, et al: PKM2 and ACVR 1C are prognostic markers for poor prognosis of gallbladder cancer. Clin Transl Oncol 16: 200-207, 2014

98. Kolev Y, Uetake H, Takagi Y and Sugihara K: Lactate dehydrogenase-5 (LDH-5) expression in human gastric cancer: association with hypoxia-inducible factor (HIF-lalpha) pathway, angiogenic factors production and poor prognosis. Ann Surg Oncol 15: 2336-2344, 2008.

99. Yu SJ, Yoon JH, Yang JI, et al: Enhancement of hexokinase II inhibitor-induced apoptosis in hepatocellular carcinoma cells via augmenting ER stress and anti-angiogenesis by protein disulfide isomerase inhibition. J Bioenerg Biomembr 44: 101-115, 2012

100. Zhou Y, Tozzi F, Chen J, et al: Intracellular ATP levels are a pivotal determinant of chemoresistance in colon cancer cells. Cancer Res 72: 304-314, 2012.

101. Vander Heiden MG, Christofk HR, Schuman E, et al: Identification of small molecule inhibitors of pyruvate kinase M2. Biochem Pharmacol 79: 1118-1124, 2010.

102. Feldman RI, Wu JM, Polokoff MA, et al: Novel small molecule inhibitors of 3-phosphoinositide-dependent kinase-1. J Biol Chem 280: 19867-19874, 2005. 